\title{
Nóg oorlog, nóg terpentyn
}

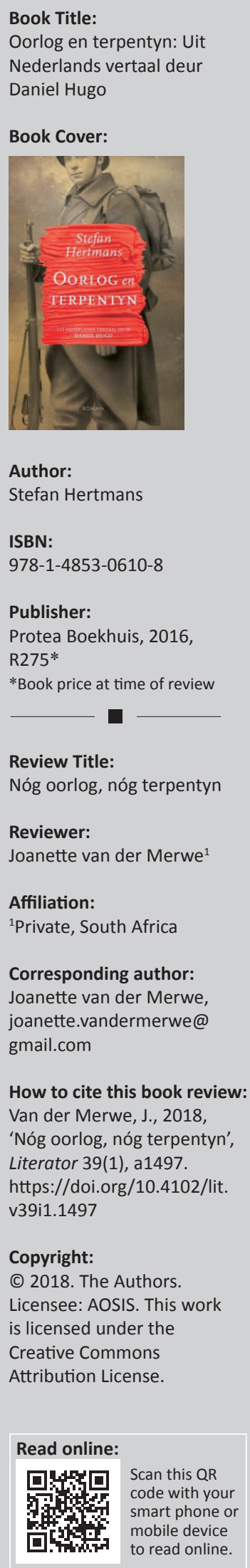

Urbain Martien - die diep gelowige Katolieke seun van 'n skilder, self 'n soldaat en kunstenaar - het in die laat negentiende eeu in armoede in Gent, België, grootgeword. In 1914 breek die Eerste Wêreldoorlog uit en die 23-jarige Urbain bevind homself in die voorste linies van die geveg. In sy laaste lewensjare teken Urbain sy herinnerings op en laat dit na aan sy kleinseun, die bekroonde Vlaamse skrywer Stefan Hertmans. Dertig jaar later verskyn Oorlog en terpentyn onder Hertmans se naam - deels biografie, deels roman, deels geskiedskrywing, deels besinning oor die aard van kuns, geheue, geskiedenis en oorlog.

Die boek is in drie dele verdeel: die eerste handel oor Urbain se kinderjare voor die oorlog; die tweede blyk 'n eerstehandse verslag te wees van Urbain se oorlogservarings; en die derde deel bevat sy lewe ná die oorlog tot en met sy dood. Terwyl Hertmans self in die eerste en derde dele geesdriftig saampraat en sy eie herinnerings aan sy oupa, sowel as sy navorsingsproses gedurende die skryf van die boek neerpen, lê die krag - en myns insiens die belang - van hierdie werk in die middelste gedeelte.

Urbain se oorlogservarings word treffend en glashelder aangebied, en die ongeromantiseerde blik op die gruwelike realiteite van die slagvelde sluit aan by klassieke oorlogverslae soos Robert Graves se Goodbye to all that. Geskryf vanuit die oogpunt van 'n Belgiese soldaat, wat boonop as Vlaming eerstehandse ervaring gehad het van die vooroordeel van die hoofsaaklik Waalse offisiere, lewer hierdie verslag 'n belangrike bydrae tot die argief van eerstepersoonsvertellings van die Eerste Wêreldoorlog. Laasgenoemde word tans nog grootliks deur Britse en Amerikaanse narratiewe oorheers.

As kunstenaar is Urbain se blik helder en vlymskerp, sprekend van die gawe om die wêreld in sy skoonheid sowel as afgryslikheid en die soms paradoksale aanwesigheid van beide - ánders te sien. Hy skets die gebeure en die landskap van die slagvelde in evokatiewe en beeldryke taal soos wanneer hy beskryf hoe 'n massa diere deur die rivier swem, vlugtend voor die vloedwater wanneer die sluise oopgemaak word in 'n poging om die vyand se opmars te stuit: '... 'n [O]nwêreldse leër. Hul gevoelige snoete trek tallose driehoeke in die gladde, swart oppervlak' (bl. 204); '[s]oos vermomde engele van die oordeelsdag verdwyn die deurweekte spookgedaantes weer buite sig, al springend oor die moddervlakte wat in die grou oggendlig swart glinster' (bl. 205).

Die eerste en derde deel van die boek is waar Hertmans se stem die luidste klink. Hy verweef die verhaal van sy oupa se kinderjare met bepeinsings oor die aard van kuns en literêre arbeid, sowel as insigte omtrent geheue, voorstelling, en kunstenaarskap. Dit is ook in hierdie gedeeltes waar die skrywer se selftwyfel omtrent sy seggenskap oor sy oupa se verhaal - en die groter narratief van die geskiedenis - plek-plek op die voorgrond gestel word. Dit kom voor asof hierdie skryfprojek 'n poging is om Hertmans se eie teenstrydige gevoelens te besweer, en die redes wat hy gee waarom hy sy oupa se memoires gepubliseer het (en so lank geneem het om dit te doen ná sy oupa se dood) is soms té verdedigend en selfgerig. Alhoewel dit deel van Hertmans se projek is om die gekonstrueerdheid van geskiedenis en geheue te ondersoek, om die lae van uitdrukking en interpretasie rondom die 'waarheid' te deurgrond, is dit asof die skrywer homself hier tussen die leser en die verhaal plaas.

Daar is ook plekke waar dit voel asof die skrywer sommige gebeure óórinterpreteer, byvoorbeeld wanneer hy die woord Cilense! in sy oupa se dagboek lees en in hierdie skryffout Urbain se ma se naam - Céline - lees: "n [g]limps van die eensaamheid, die onderdrukte heimwee, die kreet na sy moeder' (bl. 143). In ander gevalle wissel die narratief skielik en skryf Hertmans asof vanuit die oogpunt van Urbain se vader (bl. 88) en moeder (bl. 128-129). In 'n geval van skynbare kunstenaarsvryheid ken hy emosies en intieme gedagtes aan sy groot-grootouers toe, wat in die konteks van 'n gedenkskrif vervreemdend werk deur twyfel te wek oor hoeveel van die ander 'herinneringe' dalk ook wensdenkery van Hertmans is. 
Die Afrikaanse vertaling deur Daniel Hugo is soepel en lees lekker; dit behou 'n sekere ritme van die oorspronklike Nederlands. Oorlog en terpentyn bevat waardevolle inligting vir 'n leser met 'n belangstelling in die Eerste Wêreldoorlog en die daaglikse bestaan in Gent rondom die draai van die vorige eeu. Die boek toon ook heelwat insig in Hertmans se eie lewe en denke, en kan vir aanhangers van hierdie skrywer interessant wees.
Dit voel wel soms asof die raamwerk van Urbain se herinnerings nie heeltemal voldoende is om Hertmans se persoonlike besinnings te dra nie, en die boek slinger effens lomp tussen sy twee pole van oorlog en terpentyn nie heeltemal genoeg van 'n roman om die artistieke vryheid te vergoeilik nie, en nie heeltemal genoeg van 'n gedenkskrif om die gebrek aan 'n sterker verhaallyn te verskoon nie. 